\title{
Johannes Juda Groen (1903-1990): A Forgotten Visionary in the History of Medical Education
}

\author{
Jochanan Benbassat, M.D.* \\ Department of Health Policy Research, Myers-JDC-Brookdale Institute, Jerusalem, Israel
}

\begin{abstract}
Beyond the increase in medical knowledge and biotechnology during the last decades, doctors have adopted professional norms that would have been considered heretical only two generations ago. The changes transpired between the 1970s and 1990s, and generated controversies between those who upheld the traditional values of patient care, and those who welcomed the new professional norms. Professor Dr Johannes Juda Groen (1903-1990) predicted and promoted some of these changes. As early as the 1940s through the 1960s, he recognized the need to teach interviewing skills and advocated an orientation to patients, rather than to diseases; he supported decision-making based on evidence, rather than on personal experience and pathophysiologic rationale; and he demonstrated that psychosocial determinants predict, rather than only correlate with, disease. These views led to confrontations with the medical establishments in the Netherlands and in Israel. Still, many of his colleagues recognized the value of his contributions. The author, for one, admires Groen's commitment in challenging the prevailing clinical wisdom after the end of World War 2, and his courage in opposing the views of his colleagues.
\end{abstract}

KEY WORDS: Evidence-based medicine, interviewing skills, Johannes Juda Groen, professional norms, psychosocial determinants of disease, psychosomatic medicine

\section{INTRODUCTION}

Today, doctors have adopted professional norms that they rejected only two generations ago. Patient autonomy replaced doctors' paternalism, and, from passive recipients of care, patients evolved to be partners in self-care. Evidence-based medicine replaced clinical decisions grounded on personal ex-

\footnotetext{
Abbreviations: WW2, World War 2.

Citation: Benbassat J. Johannes Juda Groen (1903-1990): A Forgotten Visionary in the History of Medical Education. Rambam Maimonides Med J 2020;11 (4):eo038. doi:10.5041/RMMJ.10395
}

Copyright: (C) 2020 Jochanan Benbassat. This is an open-access article. All its content, except where otherwise noted, is distributed under the terms of the Creative Commons Attribution License (http://creativecommons.org/licenses/by/3.0), which permits unrestricted use, distribution, and reproduction in any medium, provided the original work is properly cited.

Conflict of interest: No potential conflict of interest relevant to this article was reported.

* E-mail: benbasat@jdc.org.il 
perience and pathophysiologic rationale. There was a move from denial to acceptance of clinical uncertainty and from the biomedical model of clinical practice to acceptance of psychosocial determinants of disease. Medical training supplanted its strict orientation to biomedicine by teaching doctor-patient relations and patient interviewing, and health-care delivery shifted from disease-centered to patientcentered care.

The earlier professional norms dominated my undergraduate and residency training at the Hadassah University Hospital in Jerusalem in the 1950s and 1960s. At that time, Professor Dr Johannes Juda Groen headed the department of Medicine A. His psychosocial orientation, reliance on evidence rather than personal experience, and promotion of what we would call today "patient-centered practice" challenged the prevailing style of clinical practice. It was only in the 1970 s that I began realizing that Groen's teaching was about 20 years ahead of its time.

After his death on June 16, 1990, the obituaries in medical journals focused on his biography and contributions to almost any field of medicine. ${ }^{1-4}$ However, they overlooked his teaching of doctorpatient relations, clinical reasoning, patient involvement in care, and taking a patient's history. The objective of this paper is to outline Groen's teaching of these issues and to speculate why it generated antagonism. It would be only fair to disclose that I am biased by my affection for Professor Groen and by my admiration of his courage in challenging the medical establishments in the Netherlands and in Israel.

\section{BIOGRAPHICAL NOTES}

Johannes Juda Groen was born in Amsterdam in 1903 and graduated from the University of Amsterdam in 1927. After spending a year at St Bartholomew's Hospital in London, he began his residency at the department of Medicine of the Wilhelmina Hospital in Amsterdam that was headed by Professor Isidore Snapper. Later, Groen said that, in examining patients, he held a mental image of Snapper looking over his shoulder. On his part, Snapper referred to Groen's diminutive body by saying: "Groen came to us a tiny man. He became the internist taller than any of us." $3(\mathrm{p} 762)$

In 1935, Groen spent a year at Harvard's Thorndike Memorial Laboratory, and on his return he was Snapper's chef de clinique until 1940. During World War 2 (WW2), Groen evaded deportation and, find- ing himself with more time than before, advised patients. He learned to encourage them to express feelings, and discovered the value of the unhurried biographical anamnesis as opposed to the standard medical history. The patients' histories appeared to support the association between personality and disease.

After WW2, Groen received from the Rockefeller Foundation a grant to study this association, and, together with psychiatrist Bastiaans, physiologist van der Valk, and psychologist Vles, he founded the Psychosomatic Workgroup. For some years, they contributed to psychophysiological research. However, Groen's hospital colleagues did not agree with his views. He was not promoted to Professor of Medicine, and in 1958 he moved to Jerusalem to chair the Department of Medicine A at the Hadassah University Hospital.

Here again, his views led to confrontations, and 10 years later, in 1968, he returned to the Netherlands in order to take up an appointment as Professor in Psychobiology in Leiden. In 1981, he received the van den Bergh Award for Achievements in Internal Medicine. While in Israel, he used to tell us, his trainees, that van den Bergh had said, "Groen is my intellectual grandson," and would remind us of our medical genealogy back to Snapper, van den Bergh, and Wenkebach.

\section{CONTRIBUTIONS TO MEDICAL KNOWLEDGE}

By the time of his death in 1990, Groen had authored about 400 publications in Dutch, English, German, French, and Hebrew, in almost every field of medicine. In 1925-1932, he studied iron, sugar, and fat intestinal absorption. . $^{-7} \mathrm{He}$ was the first to observe the decline in serum potassium during recovery from diabetic ketoacidosis, ${ }^{8}$ to quantitate the activity of plasma insulin on the isolated rat diaphragm, ${ }^{9}$ and to note the associations of Gaucher's disease with constrictive pericarditis, ${ }^{10}$ paradental disease with pre-senile osteoporosis, ${ }^{11}$ and osteomalacia in Bedouins with their poor exposure to sunlight. ${ }^{12}$

In the 1950s, Groen confirmed prospectively the increased mortality of hypertensive patients, and showed that heart, kidney, and retinal involvement predicted a reduced survival. ${ }^{13}$ After observing that Benedictine monks had higher serum cholesterol levels than vegetarian Trappist monks, ${ }^{14}$ he formulated one of the first cholesterol-lowering diets and 
demonstrated its effect by a controlled trial. ${ }^{15} \mathrm{He}$ also demonstrated that substitution of saturated fat by bread reduced serum cholesterol in human volunteers. ${ }^{16}$ In the 1960 , he was a recognized authority on diet-lipid-heart disease relations ${ }^{17}$ and chaired the World Health Organization Expert Committee on Cardiovascular Disease and Hypertension.

Groen is most remembered for his claim that psychosomatic disorders are patterns of behavior enforced by the socio-cultural environment that blocks psychiatric manifestations and favors their substitution by somatic syndromes. ${ }^{18}$ The premise that environmental norms affect disease patterns was consistent with the decline of peptic ulcer, asthma, and ulcerative colitis during the German occupation of the Netherlands in WW2, ${ }^{19}$ and with the lower prevalence of ulcerative colitis and coronary heart disease among oriental than among occidental Jews in Israel. ${ }^{20,21}$ The hypothesis that the environment affects behavior and disease was also supported by the higher aggression and abortion rates of hamsters that had been handled by forceps only, than of hamsters handled gently by human hands. ${ }^{22}$

After observing that paralyzed patients had higher blood pressure than age- and gender-matched controls, ${ }^{23}$ Groen suggested that being dependent on others produces a feeling of suppressed frustration. The hypothesis that central nervous functions play a role in the pathogenesis of hypertension was consistent with the behavior of rats with genetic predisposition to hypertension. ${ }^{24}$ Finally, Groen participated in the Israeli Ischemic Heart Disease Project, a prospective annual follow-up of 10,000 male government employees, that began in 1960 . One of the findings of this project was that a subject's perception of his wife as loving reduced his risk of angina even in the presence of other risk indicators. ${ }^{25,26}$ This observation remains one of the few indications of a temporal relationship (rather than of a mere association) between psychosocial determinants and disease.

\section{J.J. GROEN'S TEACHING AND CONTRIBUTION TO THE CHANGE IN PROFESSIONAL NORMS}

Groen should be credited for contributing to clinical practice not only by his (now mostly outdated) studies, but also by promoting four professional norms that the medical orthodoxy adopted only 20 years later. First, he encouraged patients to par- ticipate in their own treatment ${ }^{27}$ even before the World Health Organization coined the term "patientcentered care" in the 1990s. Second, he recognized psychosocial determinants of disease, even before Holmes and Rahe observed an association between life events and disease ${ }^{28}$ and even before Antonovsky drew attention to the association between socioeconomic status and mortality 29 in 1967. Third, he recognized the need for teaching interviewing skills even before Morgan and Engel's call to incorporate patient interviewing into undergraduate medical programs $3^{30}$ in 1969. Fourth, he supported decisionmaking based on evidence, even before Guyatt and colleagues coined the phrase "evidence-based medicine" 31 in 1992.

In the 1950s, doctors' behavior was paternalistic. Patients were thought to be too anxious to be trusted even with measuring their own weight. Yet, Groen argued that patients should be educated for selfcare. In the 1950s, doctors dismissed Groen's recognition of psychosocial determinants of disease. Yet, after seeming to be extinct for almost two decades, psychosomatic medicine returned in the 1970 s to the mainstream, and today doctors attempt to provide support and treatment for both the biomedical and psychosocial components of a patient's predicament.

Doctors have always known that the patient's story is important ("listen to the patient; he is telling you the diagnosis"). However, the recognition that medical students need help in learning how to communicate with patients is a recent development in medical education. In the 1950s, faculty regarded talking with patients as a simple undertaking that did not merit instruction, and students graduated without ever interviewing a patient while supervised. On the other hand, already in the 1940s, Groen recognized the value of encouraging patients to express feelings. During his rounds in Israel, he frequently attempted to demonstrate how to talk to patients, evoke their feelings, and express empathy. He advised us to overcome a patient's deafness by speaking softly close to his/her ear rather than shouting ("one cannot shout and be gentle at the same time"). He taught us how to encourage the patient's narrative ("simply repeat his/her last word and wait"); to express willingness to listen to the patients' feelings ("Ask the patient: what worries you most?"); and to never contradict patients in distress.

Groen questioned the validity of clinical decisions based on unsystematic personal experience or 
pathophysiologic rationale. Cases in point were his disapproval of quinidine treatment for ventricular premature contractions, and norepinephrine for cardiogenic shock. It was only in the 1990 s that doctors became aware that intuition, personal experience, and pathophysiologic rationale are insufficient for clinical decisions. In 1992, Guyatt and colleagues coined the phrase "evidence-based medicine" that stresses the value of inferences from clinical trials. ${ }^{31}$ Parenthetically, such trials showed that Groen was right in opposing quinidine treatment of arrhythmia, but not in opposing norepinephrine treatment of cardiogenic shock.

Several of Groen's views remain unconfirmed. ${ }^{2-34}$ He supported the theory of psychosomatic specificity that posits that a specific set of circumstances in an individual with specific personality traits would result in a specific disease. Its ultimate proof would be if subjects selected for a specific personality trait would develop a specific disorder during follow-up. To my knowledge, such a study has not been performed. Still, Groen inferred from the life histories of six patients with ulcerative colitis that they shared high intelligence, sensitivity, and lack of aggression, 35 and from the histories of 24 male patients with a myocardial infarction that they shared, in conflict situations, an exaggeration of the male behavior in the Western culture. ${ }^{36}$

The alternative to psychosomatic specificity is the theory of psychosomatic non-specificity that posits that any life event or any unfavorable psychosocial circumstances may increase the risk of any disease, irrespective of personality traits. This theory accommodates the associations between life events and all-cause morbidity and between socioeconomic state and all-cause mortality. Yet, as of today, the nature of the relationship between disease and psychosocial determinants remains uncertain.

\section{PERSONAL REFLECTIONS: WHY GROEN'S COLLEAGUES REJECTED HIS CONCEPTS}

Most probably, Groen's colleagues rejected his concepts in the 1950 os and 1960 s because of the medical profession's habitual opposition to any change. His support of psychosocial determinants of disease challenged the orthodox biomedical model of practice. This model posited that all diseases are structural or biochemical abnormalities. However, it blunted physicians' sensitivity to the emotional aspects of human illness and promoted a practice based on deductions from pathophysiological mechanisms. It was only later that doctors realized that the biomedical model did not accommodate the association between life events and morbidity and between socio-economic level and mortality, and subsequently adopted the bio-psychosocial model of practice.

Groen's mistrust of unsystematic personal experience challenged the belief in the accuracy of "intuitive reasoning" and in the value of the "art of medicine." In the 1950s, intuitive reasoning satisfied clinical needs. For the most part, doctors were unaware of anything wrong with their clinical decision-making, or that it was in need of improvement. It was only later that awareness of the frequent medical errors and disagreement between experienced clinicians led to a critical analysis of clinical decision-making and adoption of evidencebased medicine. In the 1950s, doctors also rejected notions of uncertainty, probability, and statistical inference. The 1965 edition of DeGowin's "Introduction to Clinical Medicine" posited that "statistical methods can only be applied to a population of thousands ... [T] he relative incidence of two diseases is completely irrelevant to ... diagnosis. A patient either has or has not a disease." 37 It was only in the 2009 edition of DeGowin's Bedside Diagnostic Examination that phrases such as "relative disease probabilities," "more or less common diseases," and "prevalence of diseases in the patient's age group" appeared in the chapter on diagnosis. ${ }^{38(\mathrm{p} 7)}$

Finally, Groen's involvement of patients in their treatment challenged the paternalistic attitude that prevailed in the 1950 os. Only later did clinical practice adopt patient self-care. Today, self-care has progressed to the point that diabetic patients adjust their insulin treatment to self-tested blood sugar levels, and patients with bronchial asthma adjust their corticosteroid medication to self-tested pulmonary function.

A second possible reason for rejecting Groen's concepts of psychosocial determinants of disease, evidence-based medicine, and patient involvement in care was his personality. Groen's confrontations with the establishment may have portrayed him as being arrogant and aggressive. However, he was neither of these. I remember him as a mild-mannered and soft-spoken scholar, who only rarely lost control of his displeasure. Nevertheless, in the Netherlands, Groen's messianic drive alienated his colleagues, while, in Israel, faculty felt he was a foreigner, and 
his behavior was a source of irritation for many of his colleagues and students.

I have no first-hand knowledge of how Groen's colleagues in the Netherlands expressed their opposition to his psychosomatic orientation after the end of World War 2. Nevertheless, it seems that, although many of his Dutch colleagues disagreed with his ideas, they still appreciated Groen's commitment and past contributions to medical knowledge. On the other hand, it would appear to me that Groen's colleagues in Israel were openly hostile to him. They derided his psychosocial orientation ("Groen treats myocardial infarction by psychotherapy"); his reliance on epidemiologic studies ("Epidemiologists deal with populations; we deal with individuals"); his mistrust of personal experience ("[Unlike Groen], we learn from a single case more than from studies of thousand cases"); and, mainly, his insistence on patient-centered practice ("Groen is nice to patients; we treat patients"). Yet, Groen never appeared upset by this hostility and never lost self-control when derided.

Why did Groen provoke such hostility in Israel? It is possible that the response of Israeli doctors to challenges of their practice was less courteous than those in the Netherlands, or that Groen's colleagues from the competing medical department felt threatened by his international prominence. Looking back, I admire his self-restraint and tolerance of mocking remarks made during faculty meetings. It would appear to me that one of the lessons of Groen's legacy is that everybody who does not deliberately harm others deserves to be treated with respect, however bizarre, uncanny, and senseless his/her ideas might seem. I feel privileged to have had him among my mentors.

\section{REFERENCES}

1. Paulley J. International college of psychosomatic medicine information exchange: Obituary Juda Johannes Groen, F.R.C.Psych., F.A.C.P., F.I.C.P.M., M.D., F.R.C.P. 1904-1990. J Psychosom Res 1991; 35:127-8. CrossRef

2. Schüffel W. Continuing friendship in the face of European destruction and European construction. Psychother Psychosom 2013;82:273-8. CrossRef

3. Blackburn H. 2oth-Century "Medical Marco Polos" in the origins of preventive cardiology and cardiovascular disease epidemiology. Am J Cardiol 2012; 109:756-67. CrossRef
4. Wolf S. In memoriam Johannes Juda Groen, M.D., FACP FRCP, 1904-1990. Psychosom Med 1991;53: 119-20. CrossRef

5. Groen J, Van Den Broek WA, Veldman H. Absorption of iron compounds from the small intestine in the rat. Biochim Biophys Acta 1947:1:315-26. CrossRef

6. Groen J. The absorption of glucose from the small intestine in deficiency disease. New Engl J Med 1938; 218:247-53. CrossRef

7. Groen J. Absorption and metabolism of lipiodol after oral administration: method for the study of fat absorption and fat metabolism in man. Am J Med 1948;4:814-26. CrossRef

8. Frenkel M, Groen J, Willebrands AF. Low serum potassium level during recovery from diabetic coma with special reference to its cardiovascular manifestations. Arch Intern Med (Chic) 1947;80:728-38. CrossRef

9. Willebrands AF, Groen J, Kamminga CE, Blickman JR. Quantitative aspects of the action of insulin on the glucose and potassium metabolism of the isolated rat diaphragm. Science 1950;112:277-8. CrossRef

10. Benbassat J, Bassan H, Milwidski H, Sacks M, Groen JJ. Constrictive pericarditis in Gaucher's disease. Am J Med 1968;44:647-52. $\underline{\text { CrossRef }}$

11. Groen JJ, Menczel J, Shapiro S. Chronic destructive periodontal disease in patients with presenile osteoporosis. J Periodontol 1968;39:19-23. CrossRef

12. Groen JJ, Eshchar J, Ben-Ishay D, Alkan WJ, BenAssa BI. Osteomalacia among the Bedouin of the Negev Desert; clinical and biochemical observations. Arch Intern Med 1965;116:195-204. $\underline{\text { CrossRef }}$

13. Frant R, Groen J. Prognosis of vascular hypertension. A nine-year follow-up study of four hundred and eighteen cases. Arch Intern Med (Chic) 1950;85:72750. CrossRef

14. Groen JJ, Tijong KB, Koster M, Willebrands AF, Verdonck G, Pierloot M. The influence of nutrition and ways of life on blood cholesterol and the prevalence of hypertension and coronary heart disease among Trappist and Benedictine monks. Am J Clin Nutr 1962;10:456-70. $\underline{\text { CrossRef }}$

15. Groen J, Tijong KB, Kamminga C, Willebrands AF. The influence of nutrition, individuality and some other factors, including various forms of stress, on the serum cholesterol; an experiment of 9 months duration in 60 normal volunteers. Voeding 1952;13: 556-87 (Dutch).

16. Groen JJ. Effect of bread in the diet on serum cholesterol. Am J Clin Nutr 1967;20:191-7. CrossRef 
17. Groen J, van der Heide RM. Atherosclerosis and coronary thrombosis. Medicine (Baltimore) 1959;38:123. CrossRef

18. Groen J. Psychosomatic disturbances as a form of substituted behavior. J Psychosomatic Res 1957;2: 85-96. CrossRef

19. Groen JJ. Influence of social and cultural patterns in psychosomatic disorders. Psychother Psychosom 1970;18:189-215. $\underline{\text { CrossRef }}$

20. Birnbaum D, Groen JJ, Kallner G. Ulcerative colitis among the ethnic groups in Israel. Arch Intern Med 1960;105:843-8. CrossRef

21. Kallner G, Groen JJ. Mortality from coronary (arteriosclerotic) heart disease and cerebrovascular accidents among eastern immigrants in Israel. J Clin Epidemiol 1968;21:25-35. CrossRef

22. Yaron E, Chovers I, Locker A, Groen JJ. Influence of handling on the reproductive behavior of the Syrian hamster in captivity. J Psychosom Res 1963;7:69-82. CrossRef

23. Welner A, Yosipovitch ZH, Groen JJ. Elevated blood pressure in children and adolescents with residual paralysis and deformities from poliomyelitis and other crippling diseases. J Chronic Dis 1966;19:115764. $\underline{\text { CrossRef }}$

24. Welner A, Ben-Ishay D, Groen JJ, Dahl LK. Behavior patterns and sensitivity to experimental hypertension in rats. Proc Soc Exp Biol Med 1968;129;886-90. CrossRef

25. Medalie JH, Snyder M, Groen JJ, Neufeld HN, Goldbourt U, Riss E. Angina pectoris among 10,000 men: 5 year incidence and univariate analysis. Am J Med 1973;55:583-94. CrossRef

26. Medalie JH, Goldbourt U. Angina pectoris among 10,000 men. II. Psychosocial and other risk factors as evidenced by a multivariate analysis of a five year incidence study. Am J Med 1976;60:910-21. CrossRef
27. Groen JJ, Pelser HE. Newer concepts of teaching, learning, and education and their application to the patient doctor cooperation in the treatment of diabetes mellitus. Pediatric Adolescent Endocrinology 1982;10:168-77.

28. Holmes TH, Rahe RH. The social readjustment rating scale. J Psychosomat Res 1967;11:213-18. CrossRef

29. Antonovsky A. Social class, life expectancy and overall mortality. Milbank Mem Fund Q 1967;45:31-73.

30. Morgan WL, Engel GL. The Clinical Approach to the Patient. Philadelphia, PA: WB Saunders Company; 1969.

31. The Evidence-Based Medicine Working Group. Evidence-based medicine. A new approach to teaching the practice of medicine. JAMA 1992;268:2420-5.

32. Groen J. The hereditary mechanism of Gaucher's disease. Blood 1948;3:1238-49.

33. Heimann-Hollaender E, Benbassat J, Groen JJ. Glucose metabolism, glutathione stability and electrolyte composition of human red blood cells. Metabolism 1962;11:245-53.

34. Groen JJ. Syndrome shift. Arch Intern Med 1964; 114:113-17. CrossRef

35. Groen J. Psychogenesis and psychotherapy of ulcerative colitis. Psychosom Med 1947;9:151-74.

36. Van der Valk JM, Groen JJ. Personality structure and conflict situations in patients with myocardial infarction. J Psychosomatic Res 1967;11:41-46. CrossRef

37. DeGowin EL. Bedside Diagnostic Examination. 1st ed. New York, NY: Macmillan Co; 1965.

38. LeBlond RF, Brown DD, DeGowin RL. DeGowin's Diagnostic Examination. 9th ed. New York, NY: McGraw-Hill; 2009:7. 